\title{
An exploration study on the effects of social media on building SMEs brands
}

\author{
Nika Hosseinjazani*
}

Department of Management and Accounting, Islamic Azad University, Central Branch, Tehran, Iran

\section{H R O N I C L E}

Article history:

Received: March 5, 2017

Received in revised format: May

16, 2017

Accepted: June 11, 2017

Available online:

June 12, 2017

Keywords:

SMEs

Project based industry

Building brand

Social media

\section{A B S T R A C T}

Social media are an integral part of modern society and they have become a big industry especially after the emergence of social medias on Mobile devices. It has been a while that most Small and Medium Enterprises (SMEs) have used social medias to promote their business activities. Social medias also supply different facilities for SMEs to help them explore their services on the market. This is more evident for those SMEs whose activities are more project based. The purpose of this paper is to find out important factors influencing on building brand using social medias for SMEs. The study designs a questionnaire in Likert scale and distributes it among 238 of SMEs' experts in food industry in city of Tehran, Iran. Using principle component analysis, the study has determined that acquiring knowledge from social media, market approach in mass media, market reaction approach in media, strategic mass media capability and social status influence the most on building brand in SMEs.

\section{Introduction}

The brand's positioning is the place in the consumers' mind that we wish our brand to own. It is the advantage we wish our consumer to perceive when they think of our brand (Alden et al., 1999). A strong brand position means that the brand maintains a unique, credible and sustainable position in consumer's mind. A successful brand's positioning justify our efforts for capturing the market (Bronnenberg \& Wathieu, 1996). The idea of brand's positioning was first introduced by Trout and Rise (1972). They believed that positioning was not something that would be done for a product or service, but something that was done with the customer's mind (Crosno et al., 2009). A company that has a better and deeper understanding of its customers' needs, the ability to market, can organize a set of customer related activities and develop the market in addition to correct orientation. In other words, it is more important to recognize the market before building a market by detecting the quality of the firm's products and also competitors (Bronnenberg \& Wathieu, 1996). Successful brand placement companies are purposefully and continuously seeking to capture, employ, and refine new ideas and ideas from their advisers, co-workers, and activities. These companies sometimes find and implement

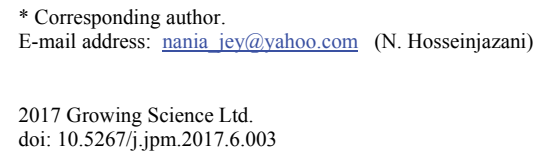


solutions through collaboration with reputable and often foreign firms (networking), and sometimes through the implementation and refinement of company's ideas and activities (Kim et al., 2001).

According to researches, the positioning is conducive for directing consumers' preferences and increasing their loyalty, enhancing the brand value of the company and the desire to search for it by customers (Blyler \& Coff, 2003). Therefore, the decision to choose an effective positioning strategy is one of the most important challenges for marketers. If an opportunity is effectively implemented, the potential of the brand will be achieved, otherwise it may cause irreparable damage (Crosno et al., 2009). In general, research in the field of brand equity has been categorized by the two consumer-oriented (outsourcing) and organization-oriented (introverted) approaches (Nagamachi, 2002). The dominant approach in previous studies is the consumer-oriented approach, which examines consumer's perceptions of a brand compared with competitors based on some specific indicators.

One of the key steps in designing an appropriate social networking strategy is the recognition and selection of media or the appropriate network in which current customers, potential clients and supporters are active. Understanding these networks will help the company know what to focus on and where. Different types of audiences of an organization, including consumer audiences, investors, shareholders, competitors, as well as the team within the organization, reflect their views on anything about the corporate and corporate website, shareholders, etc. on their social pages and share these ideas with others (Nguyen et al., 2015). In other words, audiences and customers participate in discussions related to companies and organizations, and these discussions provide companies with useful information in marketing research, which is based on the business strategy in a modern intelligent environment. On social networks, people create news, ideas and information and use them as a consumer.

Companies and organizations may also use the existing information on social media in their marketing research. Therefore, the intelligent environment resulting from social networks creates a background for customers and consumers' participation in the production process, advertising, marketing, sales, and even after-sales services of organizations and companies. Connections in social networks are based on the Internet's structure by computers, and today more and more are being transferred to the mobile phone, which is also considered as the best method to share different ideas. Because the way mobile phones communicate with computers is different. A mobile phone is always available and belongs to a person and identifying people is easier. The fact that social networks can be used simultaneously by millions of valuable users and audiences has made controlling the market more convenient and faster for marketing management. On the other hand, this kind of continuous relationship with the market in assessing and evaluating product quality, product price, and customer satisfaction helps market management. This sensing and evaluation will be done more quickly than other methods, and will provide more comprehensive and realistic information to the organization. So a brand with the help of social networks becomes more reputable than other places and tools since word of mouth advertisement in social network works better than other techniques. On the other hand, the market-oriented organization is able to better identify the needs and demands of the target market and thus, in comparison with competitors, it achieves more customer satisfaction with efficiency and effectiveness. In this way, a market-oriented organization is more likely to have higher market share and profit than other organizations with less marketing activities. Thus, the main question of this survey is as follows,

What are the factors influencing social media on brand positioning and how is it structured?

\section{The proposed method}

The survey attempts to find important factors influencing social media or brand positioning. Table 1 summarizes some of the most important variables. The study designs a questionnaire in Likert scale and distributes it among 238 of SMEs' experts in food industry in city of Tehran, Iran. The questionnaire was shared by some expert prior to survey and they confirmed the overall questions. In addition, 
Cronbach alpha has been calculated as 0.879 , which was well above the desirable level. Kaiser-MeyerOlkin Measure of Sampling Adequacy was calculated as 0.824 and Bartlett's Test of Sphericity yields a Chi-Square value of 2931.710 with Sig. $=0.000$. These preliminary tests confirm the overall questionnaire and we now use principle component analysis. Fig. 1 also shows the Scree plot, which yields 5 categories.

Table 1

The summary of the variables influencing social media or brand positioning

\begin{tabular}{|c|c|c|}
\hline Row & Variable & Reference \\
\hline 1 & Information collection from customers & Adler \& Kwon, 2002 \\
\hline 2 & Information collection from customers & Alegre et al., 2013 \\
\hline 3 & Information collection from customers & Gupta, et al., 2010 \\
\hline 4 & Innovations by Media & Heggestuen, 2013 \\
\hline 5 & Created by media needs & Kim \& Ko, 2012 \\
\hline 6 & Discover opportunities by media & Kim \& Ko, 2012 \\
\hline 7 & Commitment to customer service & Kim \& Ko, 2012 \\
\hline 8 & Leading the competition & Larrañeta et al., 2012 \\
\hline 9 & Measure customer satisfaction by media & Cadwallader et al., 2010 \\
\hline 10 & Quick awareness by the media & Burgers et al., 2008 \\
\hline 11 & Ability to lead the organization in the media & Li et al., 2012 \\
\hline 12 & Instant notification of new business & Li et al., 2012 \\
\hline 13 & Brand image & Gupta et al., 2010 \\
\hline 14 & Market share & Heggestuen, 2013 \\
\hline 15 & Customer commitment & Cadwallader et al., 2010 \\
\hline 16 & Participation in international exhibitions & Burgers et al., 2008 \\
\hline 17 & Human resources & Gupta et al., 2010 \\
\hline 18 & Organizational capabilities & Brauer \& Bourhis, 2006 \\
\hline 19 & Differentiated products & Adler \& Kwon, 2002 \\
\hline 20 & State support of industry & Alegre et al., 2013 \\
\hline 21 & Inter-agency coordination & Gupta et al., 2010 \\
\hline 22 & Networking & Heggestuen, 2013 \\
\hline 23 & Value chain & Gupta et al., 2010 \\
\hline 24 & Systematic resource combining & Adler \& Kwon, 2002 \\
\hline 25 & Customer needs & Adler \& Kwon, 2002 \\
\hline 26 & The level of trust between stakeholders in the & Kim \& Ko, 2012 \\
\hline 27 & Customer Relationship Management & Gupta et al., 2010 \\
\hline 28 & Internet marketing & Larrañeta et al., 2012 \\
\hline 29 & The foreign sales department & Melewar \& Nguyen, 2014 \\
\hline 30 & Integration & Quinton, 2013 \\
\hline 31 & Social Networks & Raju et al., 2011 \\
\hline 32 & Social campaigns & Stock et al., 2013 \\
\hline
\end{tabular}

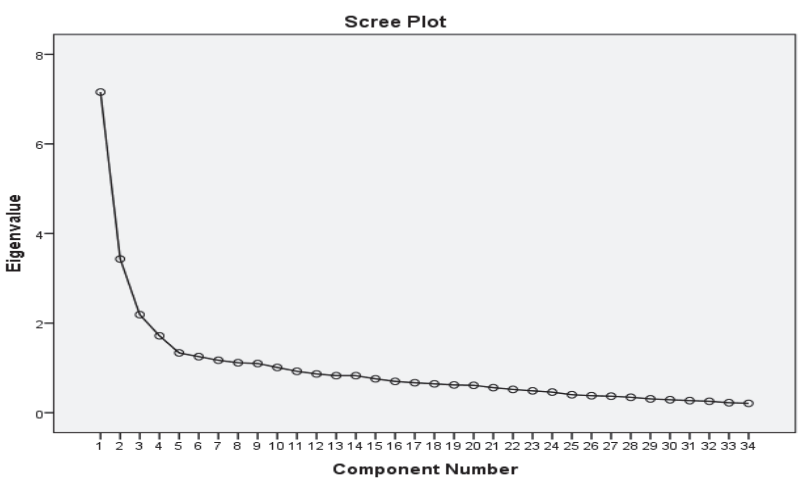

Fig. 1. The Scree-plot

Since principle component analysis is sensitive to some basic statistics, we have measured mean and standard deviation and Table 2 shows our survey. Table 3 also shows the results of communalities. Table 4 shows the results of extracted factors. In addition, Table 5 also summarizes the factor loading after the rotation happens. 
Table 2

The summary of some basic statistics

\begin{tabular}{|c|c|c|c|c|c|}
\hline Attribute & Mean & Variance & Correlation (R) & $\mathbf{R}^{2}$ & Cronbach alpha \\
\hline $\mathrm{q} 1$ & 120.0284 & 201.952 & .168 & .316 & .818 \\
\hline q2 & 119.9384 & 192.315 & .496 & .758 & .806 \\
\hline q3 & 120.0711 & 191.628 & .517 & .675 & .805 \\
\hline q4 & 120.1043 & 199.761 & .252 & .355 & .814 \\
\hline q5 & 120.5735 & 196.474 & .294 & .430 & .813 \\
\hline q6 & 119.8720 & 199.036 & .253 & .478 & .815 \\
\hline q7 & 120.3981 & 193.965 & .304 & .348 & .813 \\
\hline q8 & 120.4550 & 191.049 & .433 & .562 & .808 \\
\hline q9 & 119.9194 & 194.903 & .375 & .621 & .810 \\
\hline q10 & 119.7014 & 195.753 & .405 & .528 & .809 \\
\hline q11 & 119.7251 & 198.124 & .333 & .556 & .812 \\
\hline q12 & 120.3602 & 198.260 & .286 & .534 & .813 \\
\hline q13 & 119.8057 & 198.443 & .324 & .431 & .812 \\
\hline q14 & 120.0000 & 194.029 & .420 & .471 & .809 \\
\hline q15 & 120.3033 & 207.946 & -.001 & .317 & .822 \\
\hline q16 & 119.8815 & 196.048 & .418 & .490 & .809 \\
\hline q17 & 120.2512 & 199.122 & .279 & .373 & .814 \\
\hline q18 & 119.4550 & 194.897 & .511 & .499 & .807 \\
\hline q19 & 119.9289 & 192.866 & .488 & .741 & .807 \\
\hline q20 & 120.0948 & 208.258 & .004 & .424 & .820 \\
\hline $\mathrm{q} 21$ & 120.0000 & 197.305 & .261 & .337 & .815 \\
\hline $\mathrm{q} 22$ & 120.0190 & 208.514 & -.006 & .343 & .820 \\
\hline $\mathrm{q} 23$ & 119.9716 & 206.190 & .086 & .186 & .818 \\
\hline q24 & 120.3791 & 200.313 & .200 & .284 & .817 \\
\hline $\mathrm{q} 25$ & 120.1848 & 198.151 & .288 & .345 & .813 \\
\hline q26 & 119.9384 & 197.982 & .295 & .449 & .813 \\
\hline q27 & 120.1090 & 196.317 & .312 & .523 & .813 \\
\hline q28 & 120.0900 & 194.092 & .407 & .379 & .809 \\
\hline q29 & 119.5450 & 197.116 & .397 & .375 & .810 \\
\hline q30 & 119.6066 & 196.478 & .394 & .548 & .810 \\
\hline $\mathrm{q} 31$ & 119.6161 & 197.761 & .374 & .517 & .811 \\
\hline q32 & 119.9336 & 200.557 & .254 & .343 & .814 \\
\hline
\end{tabular}

Table 3

The summary of communalities

\begin{tabular}{clcc}
\hline Attribute & Variable & initial & Extracted \\
\hline q8 & Gathering information from customers & 1.000 & 0.595 \\
q9 & Gathering information from competitors & 1.000 & 0.79 \\
q6 & Collecting information from suppliers & 1.000 & 0.727 \\
q3 & Innovations by Media & 1.000 & 0.608 \\
q17 & Created by media needs & 1.000 & 0.628 \\
q15 & Discover opportunities by media & 1.000 & 0.666 \\
q25 & Commitment to customer service & 1.000 & 0.638 \\
q27 & Leading the competition & 1.000 & 0.683 \\
q26 & Measure customer satisfaction by media & 1.000 & 0.711 \\
q30 & Quick awareness by the media & 1.000 & 0.657 \\
q29 & Ability to lead the organization in the media & 0.698 \\
q32 & Instant notification of new business opportunities & 1.000 & 0.71 \\
q12 & Brand image & 1.000 & 0.551 \\
q13 & Market share & 1.000 & 0.613 \\
q11 & customer commitment & 1.000 & 0.534 \\
q18 & Participation in international exhibitions & 1.000 & 0.61 \\
q19 & human resources & 1.000 & 0.619 \\
q35 & Organizational capabilities & 1.000 & 0.685 \\
q28 & Differentiated products & 1.000 & 0.777 \\
q24 & State support of industry & 1.000 & 0.589 \\
q22 & Inter-agency coordination & 1.000 & 0.729 \\
\hline
\end{tabular}


Table 4

The results of extracted factors using principal component analysis

\begin{tabular}{|c|c|c|c|c|c|c|c|c|c|}
\hline \multirow[t]{2}{*}{ Factor } & \multicolumn{3}{|c|}{ Initial values } & \multicolumn{3}{|c|}{ Extracted components } & \multicolumn{3}{|c|}{$\begin{array}{l}\text { Extracted components } \\
\text { after rotations }\end{array}$} \\
\hline & Total variance & $\%$ & Cum. & Total variance & $\%$ & Cum. & Total variance & $\%$ & Cum. \\
\hline 1 & 5.668 & 17.177 & 17.177 & 5.668 & 17.177 & 17.177 & 3.8 & 11.514 & 11.514 \\
\hline 2 & 3.551 & 10.761 & 27.938 & 3.551 & 10.761 & 27.938 & 3.702 & 11.219 & 22.733 \\
\hline 3 & 2.256 & 6.836 & 34.774 & 2.256 & 6.836 & 34.774 & 2.191 & 6.639 & 29.372 \\
\hline 4 & 2.198 & 6.66 & 41.434 & 2.198 & 6.66 & 41.434 & 2.132 & 6.459 & 35.831 \\
\hline 5 & 1.771 & 5.368 & 46.802 & 1.771 & 5.368 & 46.802 & 2.115 & 6.409 & 42.24 \\
\hline 6 & 1.468 & 4.45 & 51.252 & & & & & & \\
\hline 7 & 1.36 & 4.12 & 55.372 & & & & & & \\
\hline 8 & 1.282 & 3.885 & 59.257 & & & & & & \\
\hline 9 & 1.13 & 3.425 & 62.683 & & & & & & \\
\hline 10 & 1.002 & 3.035 & 65.718 & & & & & & \\
\hline 11 & 0.932 & 2.825 & 68.543 & & & & & & \\
\hline 12 & 0.842 & 2.552 & 71.095 & & & & & & \\
\hline 13 & 0.792 & 2.399 & 73.494 & & & & & & \\
\hline 14 & 0.753 & 2.282 & 75.775 & & & & & & \\
\hline 15 & 0.678 & 2.054 & 77.829 & & & & & & \\
\hline 16 & 0.651 & 1.973 & 79.802 & & & & & & \\
\hline 17 & 0.639 & 1.936 & 81.738 & & & & & & \\
\hline 18 & 0.561 & 1.701 & 83.439 & & & & & & \\
\hline 19 & 0.554 & 1.679 & 85.118 & & & & & & \\
\hline 20 & 0.539 & 1.634 & 86.752 & & & & & & \\
\hline 21 & 0.49 & 1.485 & 88.238 & & & & & & \\
\hline 22 & 0.466 & 1.413 & 89.65 & & & & & & \\
\hline 23 & 0.454 & 1.376 & 91.026 & & & & & & \\
\hline 24 & 0.424 & 1.286 & 92.313 & & & & & & \\
\hline 25 & 0.413 & 1.253 & 93.565 & & & & & & \\
\hline 26 & 0.372 & 1.127 & 94.692 & & & & & & \\
\hline 27 & 0.355 & 1.075 & 95.767 & & & & & & \\
\hline 28 & 0.309 & 0.936 & 96.703 & & & & & & \\
\hline 29 & 0.25 & 0.758 & 97.461 & & & & & & \\
\hline 30 & 0.245 & 0.741 & 98.202 & & & & & & \\
\hline 31 & 0.234 & 0.708 & 98.91 & & & & & & \\
\hline 32 & 0.208 & 0.631 & 99.541 & & & & & & \\
\hline
\end{tabular}

\section{Table 5}

The results of factor loading after the rotation happens

\begin{tabular}{|c|c|c|c|c|c|c|c|c|}
\hline \multirow{2}{*}{ Row } & \multirow{2}{*}{ Attribute } & \multicolumn{7}{|c|}{ Factors } \\
\hline & & 1 & 2 & 3 & 4 & 5 & 6 & 7 \\
\hline q8 & Gathering information from customers & 0.809 & & & & & & \\
\hline q9 & Gathering information from competitors & 0.697 & & & & & & \\
\hline q6 & Collecting information from suppliers & 0.657 & & & & & & \\
\hline $\mathrm{q} 3$ & Innovations by Media & & 0.709 & & & & & \\
\hline q17 & Created by media needs & & 0.636 & & & & & \\
\hline q15 & Discover opportunities by media & & 0.597 & & & & & \\
\hline $\mathrm{q} 25$ & Commitment to customer service & & & 0.753 & & & & \\
\hline q27 & Leading the competition & & & 0.713 & & & & \\
\hline $\mathrm{q} 26$ & Measure customer satisfaction by media & & & 0.611 & & & & \\
\hline $\mathrm{q} 30$ & Quick awareness by the media & & & 0.592 & 0.376 & & & \\
\hline q29 & Ability to lead the organization in the media & & & & 0.748 & & & \\
\hline $\mathrm{q} 32$ & Instant notification of new business opportunities & & & & 0.686 & & & \\
\hline q12 & Brand image & & & & & 0.8 & & \\
\hline $\mathrm{q} 13$ & Market share & & & & & 0.622 & 0.359 & \\
\hline q11 & customer commitment & 0.455 & & & & 0.535 & & \\
\hline q18 & Participation in international exhibitions & & & & & & 0.846 & \\
\hline q19 & human resources & & & & & & 0.759 & \\
\hline $\mathrm{q} 35$ & Organizational capabilities & & & & & & & \\
\hline $\mathrm{q} 28$ & Differentiated products & & & 0.423 & & & & \\
\hline $\mathrm{q} 24$ & State support of industry & & & & & & & \\
\hline $\mathrm{q} 22$ & Inter-agency coordination & & & & 0.396 & & & \\
\hline
\end{tabular}


After identifying the factors that are empirically related to each other, it is necessary to try to empirically share the variables that are loaded on a given factor into the inference of the conceptual subscription. Table 6 shows the results of our work. Fig. 2 demonstrates the results of factor loading.

\section{Table 6}

The results of the factors loading in terms of different categories

\begin{tabular}{cccc}
\hline Factor & Attributes & Factor loading & Question \\
\hline Knowledge of & Gathering information from customers & .809 & $\mathrm{q} 8$ \\
social media & Gathering information from competitors & .697 & $\mathrm{q} 9$ \\
& Collecting information from suppliers & .657 & $\mathrm{q} 6$ \\
\hline $\begin{array}{c}\text { Market approach in } \\
\text { mass media }\end{array}$ & Innovations by Media & .709 & $\mathrm{q} 3$ \\
& Created by media needs & .636 & $\mathrm{q} 17$ \\
\hline Market reaction on & Discover opportunities by media & .597 & $\mathrm{q} 15$ \\
social media & Commitment to customer service & .753 & $\mathrm{q} 25$ \\
approach & Leading the competition & .713 & $\mathrm{q} 27$ \\
\hline Strategic ability to & Measure customer satisfaction by media & .611 & $\mathrm{q} 26$ \\
mass media & Quick awareness by the media & .376 & $\mathrm{q} 30$ \\
& Ability to lead the organization in the media & .748 & $\mathrm{q} 29$ \\
\hline social position & Instant notification of new business opportunities & .686 & $\mathrm{q} 32$ \\
\hline & Brand image & .800 & $\mathrm{q} 12$ \\
\hline
\end{tabular}

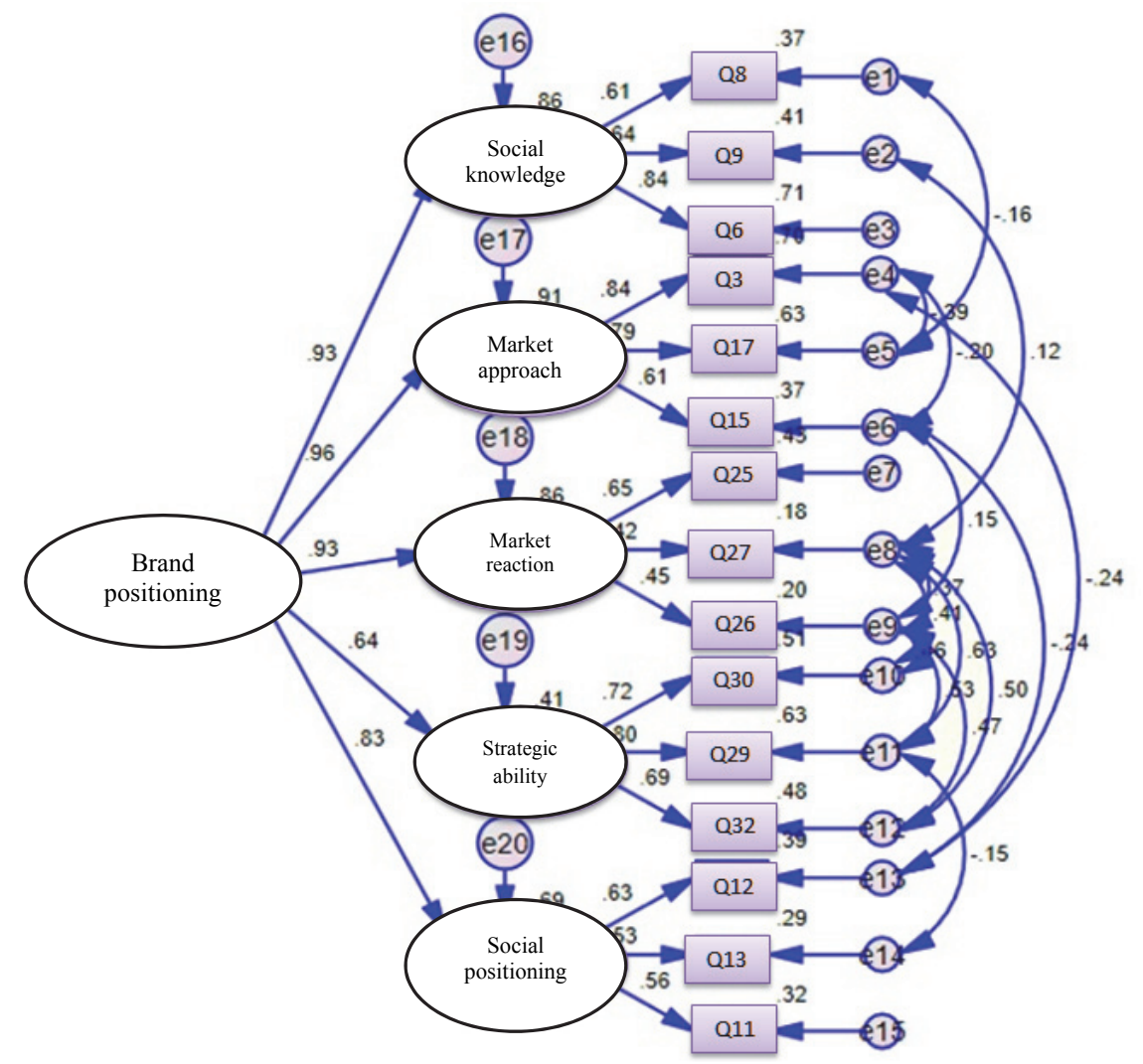

Fig. 2. The results of factor loading

Finally, for the implementation of structural equation modeling performed in this survey, we need to perform some statistical tests to verify the reliability of the test. Table 7 demonstrates the results of some basic statistics on the model. As we can observe from the results of Table 7, all statistics are within the desirable levels. 
Table 7

The summary of the statistical tests

\begin{tabular}{ccccccccccc}
\hline Attribute & X2/df & RMSEA & NFI & CFI & IFI & RFI & GFI & PRATIO & PNFI & PCFI \\
\hline Desirable level & $<2$ & $<0.05$ & $>0.9$ & $>0.9$ & $>0.9$ & $>0.9$ & $>0.9$ & $>0.5$ & $>0.5$ & $>0.5$ \\
$\begin{array}{c}\text { Knowledge of social } \\
\text { media }\end{array}$ & 1.35 & 0.03 & 0.97 & 0.99 & 0.99 & 0.95 & 0.63 & 0.61 & 0.63 & 0.02 \\
$\begin{array}{c}\text { Market approach in } \\
\text { mass media }\end{array}$ & 1.36 & 0.03 & 0.97 & 0.99 & 0.99 & 0.95 & 0.57 & 0.56 & 0.57 & 0.03 \\
$\begin{array}{c}\text { Market reaction on } \\
\text { social media ap- } \\
\text { proach }\end{array}$ & 1.26 & 0.026 & 0.95 & 0.99 & 0.99 & 0.93 & 0.69 & 0.66 & 0.68 & 0.03 \\
$\begin{array}{c}\text { Strategic ability to } \\
\text { mass media }\end{array}$ & 1.81 & 0.046 & 0.97 & 0.98 & 0.98 & 0.96 & 0.66 & 0.64 & 0.65 & 0.025 \\
\hline social position & 1.78 & 0.045 & 0.88 & 0.94 & 0.94 & 0.87 & 0.9 & 0.79 & 0.85 & 0.031 \\
\hline
\end{tabular}

\section{Conclusion}

In this paper, we have presented an empirical investigation on the effects of social media on building SMEs brands. The proposed study designed a questionnaire consists of 32 questions and distributed it among some experts in food industry who were involved in SMEs projects. The results have indicated that that acquiring knowledge from social media, market approach in mass media, market reaction approach in media, strategic mass media capability and social status influence the most on building brand in SMEs.

\section{Acknowledgement}

The authors would like to thank the anonymous referees for constructive comments on earlier version of this paper.

\section{References}

Alden, D. L., Steenkamp, J. B. E., \& Batra, R. (1999). Brand positioning through advertising in Asia, North America, and Europe: The role of global consumer culture. The Journal of Marketing, 63(1), 75-87.

Alegre, J., Sengupta, K., \& Lapiedra, R. (2013). Knowledge management and innovation performance in a high-tech SMEs industry. International Small Business Journal, 31(4), 454-470.

Adler, P. S., \& Kwon, S. W. (2002). Social capital: Prospects for a new concept. Academy of management review, 27(1), 17-40.

Brauer, M., \& Bourhis, R. Y. (2006). Social power. European Journal of Social Psychology, 36(4), 601-616.

Blyler, M., \& Coff, R. W. (2003). Dynamic capabilities, social capital, and rent appropriation: Ties that split pies. Strategic management journal, 24(7), 677-686.

Bronnenberg, B. J., \& Wathieu, L. (1996). Asymmetric promotion effects and brand positioning. Marketing Science, 15(4), 379-394.

Burgers, J. H., Van Den Bosch, F. A., \& Volberda, H. W. (2008). Why new business development projects fail: coping with the differences of technological versus market knowledge. Long Range Planning, 41(1), 55-73.

Cadwallader, S., Jarvis, C. B., Bitner, M. J., \& Ostrom, A. L. (2010). Frontline employee motivation to participate in service innovation implementation. Journal of the Academy of Marketing Science, 38(2), 219-239. 
Crosno, J. L., Freling, T. H., \& Skinner, S. J. (2009). Does brand social power mean market might? Exploring the influence of brand social power on brand evaluations. Psychology \& marketing, 26(2), 91-121.

Gupta, S., Melewar, T. C., \& Bourlakis, M. (2010). Transfer of brand knowledge in business-to-business markets: a qualitative study. Journal of Business \& Industrial Marketing, 25(5), 395-403.

Heggestuen, J. (2013). One in every 5 people in the world own a smartphone, one in every 17 own a tablet. Business Insider, 15.

Kim, C. K., Han, D., \& Park, S. B. (2001). The effect of brand personality and brand identification on brand loyalty: Applying the theory of social identification. Japanese Psychological Research, 43(4), 195-206.

Kim, A. J., \& Ko, E. (2012). Do social media marketing activities enhance customer equity? An empirical study of luxury fashion brand. Journal of Business Research, 65(10), 1480-1486.

Larrañeta, B., Zahra, S. A., \& González, J. L. G. (2012). Enriching strategic variety in new ventures through external knowledge. Journal of Business Venturing, 27(4), 401-413.

Li, Y., Hou, M., Liu, H., \& Liu, Y. (2012). Towards a theoretical framework of strategic decision, supporting capability and information sharing under the context of Internet of Things. Information Technology and Management, 13(4), 205-216.

Melewar, T. C., \& Nguyen, B. (2014). Five areas to advance branding theory and practice. Journal of Brand Management, 21(9), 758-769.

Nagamachi, M. (2002). Kansei engineering as a powerful consumer-oriented technology for product development. Applied ergonomics, 33(3), 289-294.

Raju, P. S., Lonial, S. C., \& Crum, M. D. (2011). Market orientation in the context of SMEs: A conceptual framework. Journal of Business Research, 64(12), 1320-1326.

Stock, R. M., Six, B., \& Zacharias, N. A. (2013). Linking multiple layers of innovation-oriented corporate culture, product program innovativeness, and business performance: A contingency approach. Journal of the Academy of Marketing Science, 41(3), 283-299.

Trout, J., \& Rise, A. (1972). Positioning cuts through chaos in marketplace. Advertising Age, 43, 5154.

Nguyen, B., Yu, X., Melewar, T. C., \& Chen, J. (2015). Brand innovation and social media: Knowledge acquisition from social media, market orientation, and the moderating role of social media strategic capability. Industrial Marketing Management, 51, 11-25.

Quinton, S. (2013). The community brand paradigm: A response to brand management's dilemma in the digital era. Journal of Marketing Management, 29(7-8), 912-932.

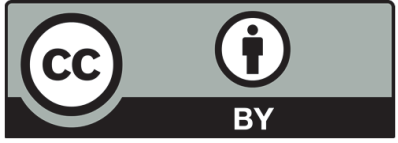

(C) 2017 by the authors; licensee Growing Science, Canada. This is an open access article distributed under the terms and conditions of the Creative Commons Attribution (CC-BY) license (http://creativecommons.org/licenses/by/4.0/). 